\title{
Evaluation of methods for sterilising boysenberry leaves for downy mildew infection studies
}

\author{
A.M. Herath Mudiyanselage, M.V. Jaspers, H.J. Ridgway, M. Walter, G.I. Langford \\ and E.E. Jones

\section{Lincoln University, Lincoln 7647, New Zealand \\ Corresponding author: anusara.herathmudiyanselage@lincolnuni.ac.nz}

Downy mildew of boysenberry, caused by Peronospora sparsa, is a major disease problem for New Zealand growers. Investigation of the biology and epidemiology of this biotrophic pathogen requires the production of sporangiospore inocula. Four leaf sterilisation treatments (70\% ethanol, 10\% bleach, sterile water, control) were assessed for their ability to reduce surface contaminants. After treatment, the leaf surfaces (six replicates) were pressed onto potato dextrose and nutrient agar plates and these were incubated at $20^{\circ} \mathrm{C}$ for 1 week. All treatments significantly $(\mathrm{P}<0.001)$ reduced both fungal and bacterial colonies compared with the untreated control. The numbers of fungal and bacterial colonies were higher on the adaxial than abaxial surfaces. To assess the effect of the treatments on susceptibility to P. sparsa infection the abaxial surface was inoculated with a $20 \mu \mathrm{l}$ spore suspension droplet $\left(2 \times 10^{4}\right.$ spores $\left./ \mathrm{ml}\right)$ and lesion development assessed after 1 month incubation at $20^{\circ} \mathrm{C}$. The sterile water treatment did not affect the susceptibility of the leaves compared with the control, whereas ethanol and bleach altered susceptibility. Therefore, sterile water can be used to reduce contamination on boysenberry leaves before infection studies.

\section{Transcriptome analysis during incompatible and compatible interactions of Ciborinia camelliae and Camellia}

\author{
M. Denton-Giles, M.P. Cox, R.E. Bradshaw and P.P. Dijkwel \\ Massey University, Palmerston North 4410, New Zealand \\ Corresponding author:m.denton-giles@massey.ac.nz
}

The host-specific fungal pathogen Ciborinia camelliae is a significant pest of ornamental Camellia plants. It is the causal agent of "Camellia flower blight", which has become rampant throughout New Zealand since the pathogen's accidental introduction in the early 1990s. This study aims to profile the infection of C. camelliae in petals of resistant Camellia lutchuensis and susceptible Camellia japonica $\times$ Camellia pitardii "Nicky Crisp" plants. Petals were harvested from glasshouse-grown plants and infected with field-collected fungal ascospores. Microscopic analysis of the incompatible interaction at 24 hours post inoculation (hpi) revealed many hallmarks of non-host resistance, including papilla formation and $\mathrm{H}_{2} \mathrm{O}_{2}$ accumulation. Localised cell death was also observed in epidermal cells in direct vicinity of ascospores. In comparison, the compatible interaction produced lesions by 30 hpi that completely enveloped the petal tissue by $72 \mathrm{hpi}$. RNA was isolated from incompatible and compatible interactions at 48 hpi. Deep sequencing of the mRNA resulted in a total of 340 million high quality cDNA reads. Preliminary analysis of the compatible transcriptome identified the expression of 23 putative fungal virulence factors that have previously been characterised in other members of the Sclerotiniaceae. 